\title{
Global Cities and Liability of Foreignness
}

\author{
Wernicke, Georg; Mehlsen, Kristian
}

Document Version

Accepted author manuscript

\section{Published in:}

European Journal of International Management

DOI:

10.1504/EJIM.2016.073983

Publication date:

2016

\section{License}

Unspecified

Citation for published version (APA):

Wernicke, G., \& Mehlsen, K. (2016). Global Cities and Liability of Foreignness. European Journal of International Management, 10(1), 78-94. https://doi.org/10.1504/EJIM.2016.073983

Link to publication in CBS Research Portal

\section{General rights}

Copyright and moral rights for the publications made accessible in the public portal are retained by the authors and/or other copyright owners and it is a condition of accessing publications that users recognise and abide by the legal requirements associated with these rights.

Take down policy

If you believe that this document breaches copyright please contact us (research.lib@cbs.dk) providing details, and we will remove access to the work immediately and investigate your claim. 


\section{Global Cities and Liability of Foreignness Kristian Mehlsen and Georg Wernicke \\ Journal article (Post print version)}

This article was originally published in European journal of International

Management, Vol 10, Issue 1, Pages 78-94.

DOI: http://dx.doi.org/10.1504/EJIM.2016.073983

Uploaded to Research@CBS: Januar २०१६ 


\title{
Global cities and liability of foreignness
}

\author{
Kristian Mehlsen \\ Department of International Economics and Management, \\ Copenhagen School of Business, \\ Copenhagen, Denmark \\ Email: $\underline{\text { mehlsen@outlook.com }}$
}

Georg Wernicke

Department of International Economics and Management, Copenhagen School of Business,

Copenhagen, Denmark

Email: gwe.int@cbs.dk 


\title{
Global cities and liability of foreignness
}

\begin{abstract}
$\underline{\text { Abstract }}$
In this article, we combine the concepts of location, liability of foreignness (LoF), and their relation to factors that drive multinational enterprises (MNEs) towards, or away from, global cities. The article is rooted in the existing literature on global cities, and it argues that three interrelated characteristics of global cities - cosmopolitanism, availability of advanced producer services, and interconnectedness - help MNEs to overcome the liability of foreignness associated with doing business abroad. In line with these arguments, we operationalize liability of foreignness as institutional distance and analyse its influence on the worldwide location of a large sample of subsidiaries of Nordic and Japanese MNEs. Our results indicate that MNEs have a stronger propensity to locate in global cities than in metropolitan or peripheral areas, and that these locational choices are affected by (the degree of) institutional distance and industrial characteristics. The results provide empirical support for our argument that locating in a global city can reduce the liability of foreignness suffered by MNEs, and that global cities play a central role in the process of globalization through attracting the majority of MNE subsidiaries.
\end{abstract}




\section{Global cities and liability of foreignness}

\section{INTRODUCTION}

In the field of international business research, a key area of interest is that of location - the where and why firms place specific activities and investments in particular areas (Enright, 2009; Goerzen, Asmussen, \& Nielsen, 2013). Researchers have traditionally focused on the nation-state as the unit of analysis in explaining where and why firms tend to cluster in a particular geographic space (Beugelsdijk, McCann, \& Mudambi, 2010). This stream of research has greatly advanced our understanding of firms' locational choices. However, firms ultimately choose a specific place within a country as the location for their investment, a state of affairs that warrants a more nuanced analysis of the characteristics of subnational locations to better understand the relationship between firms' locational choices and the spatial environment (Sassen, 2005; Brown, Derudder, Parnreiter, Pelupessy, Taylor, \& Witlox, 2010; Beugelsdijk et al., 2010).

While the question of what particular places and locational features attract firms is addressed on the subnational level of both regions (Porter, 2001) and industry clusters (Porter, 1998), the level of cities, or more specifically the concept of "global cities" developed within economic geography, has received little attention (Nachum \& Wymbs, 2005; Goerzen et al., 2013). This is surprising, as global cities (of which New York, London, Tokyo, and Shanghai are prime examples) have a number of locational advantages that make them key nodes in the global spatial organization of production and markets and in the concentration and accumulation of international capital (Friedman, 1986; Scott, 2001; McCann, 2008).

The literature on global cities has converged on three defining characteristics of them. These are cosmopolitanism, availability of advanced producer services, and global and local interconnectedness. One advantage of these global city characteristics that has been proposed in 
the small body of the respective literature is their potential to reduce the adverse consequences stemming from liability of foreignness (LoF) (Nachum, 2003; Goerzen et al., 2013) - that is, the costs experienced by foreign firms of doing business in a host country that would not be incurred by local firms (Zaheer, 1995).

Given that LoF is a core strategic issue for managers of multinational enterprises (MNEs) (Eden \& Miller, 2004) and that firms' locational choices are at the heart of international business strategy (Ricart, Enright, Ghemawat, Hart, \& Khanna, 2004), we propose that further insights into the relationship between global cities and LoF would enhance our currently rather incomplete understanding of the geographic aspects of MNE behaviour (McCann, 2011).

Since MNEs are the dominant players in globalization because they circulate knowledge, technologies, and people across the globe, understanding globalization better requires a more thorough understanding of the locational choices of MNEs (McCann, 2008). Therefore, by expanding our knowledge on MNE location and the interaction between global cities and LoF, we can contribute to the current understanding of the process of globalization, the role of policymakers in creating institutional environments that are conducive to the attraction of foreign MNEs, and the ways in which LoF can be mitigated via location strategies on the subnational level.

\section{LITERATURE REVIEW}

Early interest in locations that are characterized by the particular advantages that they offer for economic development dates back to the work of Marshall (1920). Notably, the concept of economic agglomeration has been studied by Porter (1998). According to Porter, different types of clusters of interconnected companies and institutions possess competitive advantages that are embedded in unique locational features of knowledge, relationships, and motivation that spur 
innovation and competitive success. Indeed, it has been found that proximity to local host-country firms matters because foreign subsidiaries are increasingly embedded in host-country knowledge networks (Phene \& Almeida, 2003) and because foreign direct investment (FDI) may in part be driven by the desire to gain knowledge from unique institutional contexts (Frost, 2001).

However, as Goerzen et al. (2013) point out, the primary perspective of the literature on these specialized producer communities has been that of the industrial district and not that of the agglomeration benefits that are unique to the economic geography of cities. This stream of literature that focuses on urban agglomerations is rooted in the works of Jacobs $(1961,1984)$, who considers aesthetics and a vibrant urban life that is rooted in the benefits of colocation and social interaction as the basis for an ecosystem of innovative urban communities and economic development, which through trade puts the city in contact with geographically separated cities. While both Marshall and Jacobs identify positive externalities that stem from geographic proximity, Storper and Venables (2004, p. 353) argue that "Marshall centres on belonging to a specialized producer community which diffuses the 'secrets' of industry, not the kind of cosmopolitan and haphazard city life described by Jacobs."

The implication of this distinction is that urban agglomerations in the Jacobsian sense make cities function as centres of learning, creativity, and innovation because they are home to many interdependent activities that are rooted in the endless occurrence of transactional encounters and experiences and in the creation and circulation of enormous quantities of information (Scott, 2011). Nonetheless, cities are not a closed ecosystem; they are highly integrated into various spheres of economic activity, as Brown et al. (2010, p. 16) summarize through the following assertion: "Vibrant cities expand economic life in ways that diversify economic processes within the city ('the little movements') that in turn lead to complex relations with other cities (the 'big wheels' of commerce)." 
Although the centripetal forces of privileged access to markets, products, labour pools, and knowledge spillovers pull companies towards urban agglomerations, the opposing centrifugal forces of commuting costs, urban land rent, dispersed resources, congestion, and pollution might hamper a city's attraction to people and companies (Krugman, 1994). In addition, the combination of the expansion of network technologies and the possibility of firms "offshoring" their operations and moving back-office operations from costly urban centres to outlying suburbs renders cities less important (Cohen, 2000). However, as Sassen (2000, p. 81) notes, despite the spatial dispersal of economic activity, "national and global markets as well as globally integrated organizations require central places where the work of globalization gets done." Since the high-quality infrastructure and managerial expertise required to provide the backbone for global economic activities tend to be embedded in "global cities," these locations provide a countering centripetal force in the global economy (Sassen, 1991, 2005).

\section{Framework of global cities}

The literature on the functionality of global cities has converged on three interrelated attributes that make cities function as centripetal forces in the local and global economy, namely cosmopolitanism, high levels of advanced producer services, and a high degree of interconnectedness to local and global markets (Beaverstock et al., 1999; Brown et al., 2010; Goerzen et al., 2013).

\section{Cosmopolitanism}

Hall (1966) identifies certain cities as being the locational preference for the headquarters of MNEs. Well-known cities such as London, Paris, and New York command privileged positions in the global urban hierarchy by virtue of their functional capabilities of power and influence within politics, trade, communications, finance, education, culture, and technology. As Hymer (1972) 
notes, the management functions of MNEs have to be located close to capital markets, the media, and the government as a result of the need for face-to-face contact at the higher levels of decisionmaking.

This theoretical prediction is supported by empirical evidence. For example, Storper and Venables (2004) identify the need for control and coordination through direct personal exchange of complex and varied information as a central force in the processes of localization of certain industries and of urbanization. The information requirements of deal-making, evaluation, and relationship adjustment are difficult to transmit at a great distance; they are therefore heavily dependent on face-to-face contact. Similarly, Glaeser and Resseger (2010) have found a strong correlation between worker productivity and size of the metropolitan population in cities with higher levels of skills, which indicates that certain locations attract a higher number of highly skilled workers and that density is important because proximity spreads knowledge more rapidly.

The effect of the agglomeration of important social factors, institutions, and multinational corporations in turn leads to the creation of a cosmopolitan environment that is conducive to the location of specialized managerial capabilities and to attracting the creative talent necessary for innovation and economic growth (Florida, 2004). In addition, cosmopolitan consumers are characterized by open-mindedness, an appreciation of diversity, and consumption habits that transcend borders. These traits are a potentially powerful segmentation base for companies as they target international consumer markets (Riefler, Diamantopoulos, \& Siguaw, 2012).

\section{Advanced producer services}

Global cities are command and control points in the world economy because of the rapid growth, the specialization, and the concentration of advanced producer service firms within them (Sassen, 1991). The worldwide dispersion of MNEs' operations makes managing, coordinating, servicing, 
and financing these firms more complex. For those reasons, MNEs choose to outsource a share of their central functions to highly specialized service firms in the advertising, finance, law, and accounting sectors. These advanced producer services firms tend to agglomerate in locations where the requirements of their services are met by the unrivalled pool of talent, expertise, and clients found in global cities (Sassen, 2005). Nonetheless, the need for information-rich environments does not lead to a concentration of advanced producer services in just a few "mega service centres." Instead, these firms locate in a whole range of cities, covering all major regions to provide their services when and where their international clients need it. Thus, a key purpose of the worldwide office network is to enable transnational business to be conducted (Brown et al., 2010; Goerzen et al., 2013). Besides, in many of these cities, other potential clients such as domestic corporations, government institutions, NGOs, and other foreign firms are also present (Beaverstock et al., 1999).

\section{Interconnectedness}

In addition, global cities possess a high degree of interconnectedness owing to their function in global commodity chains as central nodes for both local and global production, distribution, and consumption, as well as to their centrality in the network of information flows (Brown et al., 2010). To enable and sustain a high degree of interconnectedness, global cities are equipped with both physical (ports, airports, a central position in the local transportation network, and so forth) and informational (access to communication links and mass media) infrastructure (Harvey, 1990). The access to major transportation nodes, the presence of major financial centres and headquarters of international institutions, and the sheer population size might contribute to both local and global interconnectedness (Friedmann, 1986). 


\section{Global cities and liability of foreignness}

Zaheer's (1995) definition of LoF characterizes the concept as the additional costs incurred by a firm operating in foreign locations that a local firm would not experience. Arguably the advantage held by local firms stems from their proximity to and familiarity with the local market and the potentially worse treatment of foreigners by the host-country government, buyers, and suppliers. Eden and Miller (2004) show through a deconstruction of the costs incurred by foreign firms that LoF encompasses both the economic and social costs of doing business abroad. Whereas economic costs are related to geographic distance and are directly measurable, social costs arise from institutional distance (within the regulatory, normative, and cognitive pillars) between the MNE's home and the host country, which causes MNEs to face higher unfamiliarity and relational and discriminatory hazards relative to local firms in the host country. As it is the regulatory and normative pillars that reflect in particular the institutional perspective's roots in economics and sociology, in this article we limit our analysis to them (Xu, Pan, \& Beamish, 2004).

Following on from Nachum (2003), Goerzen et al. (2013) have found that limited attention has been paid to the subnational determinants of LoF. However, building on our analysis of the functional capabilities of global cities, we argue that the hazards associated with LoF are lower for those MNEs that establish themselves in global cities rather than in any other location.

\section{Unfamiliarity hazards}

A company's unfamiliarity with and lack of roots in a local environment make it more difficult for that organization to comply with a host country's legal environment (Mezias, 2002a, 2002b) or to understand the social values of the normative institutions (Kostova \& Zaheer, 1999). Consequently, the risks of expensive dispute settlements, failed product launches, and unsuccessful business dealings are likely to increase in institutionally distant countries. 
Global cities can reduce this unfamiliarity by providing a cosmopolitan environment that is more open to different cultures. This environment includes an agglomeration of advanced producer services that offer consultation and advice to MNEs, and it thus accelerates forms of learning and interconnectedness that permit global media and extensive IT infrastructure to reduce search costs.

\section{Relational hazards}

Unlike local firms, foreign firms face the difficulty of managing intrafirm and interfirm relations in the context of different institutional environments; this difficulty potentially hampers managerial effectiveness and increases administrative costs. Regulatory distance in the form of variations in the enforcement of (intellectual) property rights protection (Xu \& Shenkar, 2002) may well increase opportunistic behaviour by partners or employees (or the MNE itself). Differences in the normative environment reduce the MNE's ability to transfer practices to the subsidiary, resulting in increased communication and coordination costs (Zaheer \& Mosakowski, 1997). However, the cosmopolitan environment of global cities enables the MNE to build relationships with other internationally oriented companies and creative talent and use expatriates to enhance coordination and control within the MNE. The presence of advanced producer services allows the MNE to work with the same service providers globally and therefore ultimately reduce coordination costs. Additionally, the interconnectedness of global cities makes the transfer of capital, people, goods, and information to and from local subsidiaries faster, cheaper, and more accurate and thus enables better intra- and interfirm relations.

\section{Discriminatory hazards}

Differential treatment from a host country's government, consumers, or public can result in discrimination. This occurs formally when foreign firms are met by rules and regulations that are different from those applied to domestic firms (Kostova \& Zaheer, 1999), or informally when 
local firms are given preferential treatment in dealings with public officials (Zaheer \& Mosakowski, 1997). Normative distance between the home country's and the host country's notions of desirable goals and their attainment may undermine the importation of MNE practices that deviate from (local) societal expectations (Xu \& Shenkar, 2002). Finally, ethnocentrism, stemming from a stereotyping of outsiders or favouritism towards insiders, can cause consumers and employees to prefer to deal with domestic firms and discriminate against foreign MNEs (Eden \& Miller, 2004). Attitudes of openness towards other cultures and diversity, as well as preferences for international consumption associated with cosmopolitanism, may make foreign firms and products more legitimate in the eyes of consumers, suppliers, employees, and other stakeholders in global cities. In addition, the local government and its policies could promote FDI, something seen in development zones in Shanghai (Wei \& Leung, 2005). Collaboration with advanced service providers could lend credibility to the MNE in the eyes of potential partners and other stakeholders. Global interconnectedness among global cities may further reduce discrimination, because local stakeholders are more likely to be exposed to international stimuli through media, consumer products, and the prevalence of foreign firms and expatriates in their near proximity.

Consequently, we expect that LoF is lower for MNEs that locate their subsidiaries in global cities. Given the tension between the external pressure on MNEs to tailor their operations to local conditions and the internal pressure to rationalize operations and transfer strategic routines across countries (Kostova \& Zaheer, 1999; Xu \& Shenkar, 2002), global cities offer attractive locations for MNEs. Our prediction is supported by the empirical evidence of Goerzen et al. (2013), who show that MNEs do gravitate towards global cities. Building upon these authors' insights, we further argue that the greater the institutional differences between the MNE's home and host country, the stronger the gravitation towards global cities. This argument leads us to formulate the following hypothesis: 
Hypothesis: The larger the institutional distance between an MNE's host and home country, the more likely it is that the MNE's foreign subsidiaries will be located within a global city.

\section{METHODS}

\section{Data}

We tested our hypothesis with a hand-collected dataset of subsidiary locations owned by MNEs that are headquartered in the Nordic countries (Denmark, Finland, Norway, and Sweden) and Japan. This set of home countries was used to shed light on the locational patterns of Nordic MNEs, which are highly exposed to foreign environments (The Economist, 2013). We included Japan as it is one of the leading countries with regards to FDI in both developed and developing countries (UNCTAD, 2013). We collected information about the locations of subsidiaries from the Corporate Affiliations database provided by LexisNexis (2013). We excluded subsidiaries located in the MNE's home country and foreign subsidiaries located in countries without global cities, in countries not covered by the secondary datasets from which we sourced our controls, and in small city-states such as Singapore and Bahrain. The final database contains 1,331 MNEs with 20,117 subsidiaries located in 73 host countries.

We used the Global Competitiveness Report (GCR) published by the World Economic Forum as the source for measuring institutional distance. The Forum's annual Executive Opinion Survey is administered to over 13,000 business leaders in over 140 countries and covers topics within the institutional environment that are of pivotal interest in this paper.

\section{Dependent variable}

City class of subsidiary location 
To distinguish global cities from other locations, we adopted the Globalization and World Cities Research Network's 2010 roster of global cities. ${ }^{1}$ The cities are ranked in descending order in terms of how integrated into the global economy they are. The list consists of a hierarchy of 47 alpha global cities, 64 beta ones, and 67 gamma ones, as well as an additional 36 highsufficiency cities and 82 sufficiency ones (GaWC, 2011; Beaverstock et al., 1999). Global cities are classified based on their global capacity, which is measured in terms of their level of advanced producer services and their global connectivity in the global city network (Taylor, 2001). These firms seek out knowledge-rich, cosmopolitan, and interconnected locations - that is, global cities in order to produce a "seamless" service for their clients, regardless of geographical scale or complexity (Sassen, 2005). As such, Taylor (2006) argues that advanced producer services are not used to define global cities and their global network because they capture the full complexity of cities (Robinson, 2005), but rather because as knowledge intensive, cutting-edge industries they serve as critical indicators of vibrant city life in the Jacobsian sense.

To classify the location of the MNEs' subsidiaries, we used three distinct categories: global city, the metropolitan area surrounding the global city, and the periphery - that is, anywhere else.

Given Friedman's (1986) argument that the economic space of cities is not limited by political or natural boundaries - and Pain's (2012) contention that service networks are flexible structures that comprise dynamic flows of people and knowledge and that use cities to engage with competitive markets at different scales - it might be tempting to consider global cities to be borderless.

However, this view, which is closely related to the issues of global hypermobility and the negation of place and spatial distance, ignores the fact that many of the resources necessary for global

\footnotetext{
${ }^{1}$ It should be noted that other contemporary attempts have been made - by Hales and Pena (2012) and the Economist Intelligence Unit (2012), for example - to create a roster of global cities. However, these studies identify fewer global cities, and as Beaverstock et al. (1999, p. 445) note: "Despite the consensus on the leading global cities, there is no agreed roster covering global cities below the highest level."
} 
economic activity are not hypermobile but deeply embedded in place (Sassen, 2000). Global cities are characterized by a high degree of centrality, through which, among other economic functions, they provide agglomeration economies and a massive concentration of information via face-to-face contact (Storper \& Venables, 2004). Sassen (2005) notes that developments in IT have distorted the spatial coordinates of centrality from the easily identifiable downtown area to the central business district (CBD) (even though the two categories often overlap). This notion corroborates the empirical findings of Gordon and McCann (2000), who show with regards to London that, unlike the surrounding metropolitan area, a concentration of finance and media industries and a high density of regional and domestic headquarters distinctively characterize the inner City of London. This observation suggests that the dynamics of global cities are highly localized in nature (Goerzen et al., 2013), even though their centrality and economic power extend further into the regional space through nodes of intense business activity (Sassen, 2005), for example via both physical and digital highways. This configuration allows for an effect of proximity that would benefit subsidiaries that are not able to locate in the CBD. We accounted for this and used a second distinct category, metropolitan, to classify subsidiary locations.

Accordingly, we coded the location of the subsidiary into three distinct categories: 0 , the periphery (that is, anywhere else); 1, the metropolitan area surrounding a global city (metro); 2, within the global city proper. Here, the global city is centred on the CBD and extends to the official city boundaries (typically a maximum radius of 10 kilometres), after which the metropolitan area encompasses the continuous urban sprawl (typically within a radius of $50 \mathrm{~km}$ from the CBD) located along major infrastructural channels. However, both delineations are dependent on the geographic properties of the global city.

Because the locations of the 20,117 subsidiaries were visually determined and manually coded, we checked whether our procedure was reliable across different coders. For this reason, we randomly 
selected 500 subsidiaries from around the world, which were then coded by the second author of this study using the very same procedure. We then calculated Krippendorff's (1980) alpha to measure agreement between the two coders. Krippendorff's alpha was 96.34\%, indicating that our coding procedure generated reliable measurements.

\section{Independent variables}

\section{Institutional distance}

We conceptualized institutional distance as regulatory differences in the setting, monitoring, and enforcement of rules and normative differences in how things should or should not be done that reflect the values and norms of a society. Here, distances between the home country of the MNE and the host country of its subsidiary might increase discriminatory, relational, and unfamiliarity hazards (Eden \& Miller, 2004). Following Xu, Pan, and Beamish's (2004) suggestion, we selected from the GCR eight items to describe the regulatory environment of a country as well as eight items to describe the normative institutional environment. We calculated the institutional distance between the host and home country of the MNE by averaging the absolute distances between the country scores on the 16 items. This distance measure differs from that of $\mathrm{Xu}$, Pan, and Beamish (2004), who for each of the two institutional pillars average the country scores on the selected items and then calculate the distance between the host and home country of the MNE. Our measure is chosen because we wanted to take the variance of the scores across countries into account while retaining a single dimension of institutional distance.

\section{Control variables}

To proxy cultural distance, we used Hofstede's data on cultural dimensions (Hofstede Centre, 2013) and derived cultural distance using Kandogan's (2012) improved method of cultural 
distance, which does not impose weights based on dimension variance or assume zero covariance between the cultural dimensions. We added population-weighted geographic distance (Mayer \& Zignano, 2011) between MNEs' home and host countries because MNEs suffer from the geographic separation of headquarters and subsidiaries located in foreign countries (Goerzen et al., 2013).

We also added a measure of the attractiveness of global cities to certain industries, rooted in the notion that global cities are especially conducive to service-providing industries (NAICS code > 400000) given the centripetal forces of privileged access to the cosmopolitan markets, labour pools, and knowledge spillovers. Conversely, goods-producing industries (NAICS code < 400000) might be repelled by the centrifugal forces of high urban land rent and wages, potential congestion, and pollution (Krugman, 1994), as well as by the adverse effect of potential outward knowledge spillovers for technologically leading firms (Alcacer \& Chung, 2007). We also included a dummy variable for advanced producer services to test if their attraction to global cities is indeed different from that of other service-providing industries (Sassen, 1991). Finally, we used the logarithmic transformation of total number of parent employees as a measure of the size of MNEs.

\section{Empirical model}

We tested our hypothesis with a multinomial logistic regression (MLR) model. Since the dependent variable is categorical with three possibilities, we modelled the choice of location as global city versus periphery and global city versus global metro, keeping locations in global cities as the reference group. We clustered observations on the parent-firm level to account for within-group (that is, within the parent and its subsidiaries) nonindependence of observations. Different subsidiaries of a parent MNE likely share certain characteristics such as access to resources or the 
overall firm strategy, but these common characteristics differ across parent MNEs, forming distinctive groups of subsidiaries clustered in a parent MNE.

\section{RESULTS}

Table 1 provides means, standard deviations, and correlations for all variables. Correlations are very small, and the variance inflation factors are less than 2, and therefore below conventional thresholds of concerns. Together, these analyses give us great confidence that multicollinearity does not pose a threat to our results.

- Insert Table 1 here -

The dominant locational choice of the subsidiaries in our sample is global cities (43\%) over a metropolitan area (32\%) or a periphery (25\%). In addition, alpha global cities and metros (47\%) are the preferred choice, followed by beta (17\%), gamma (7\%), and the sufficiency cities and metros $(5 \%)$.

The results of testing our hypothesis are reported in Table 2.

- Insert Table 2 here -

Consistent with our hypothesis, subsidiaries are more likely to be located in global cities than in peripheral areas when institutional distance is large $(b=-0.98 ; \mathrm{p}<0.001)$. Additionally, institutional distance also influences the relative probability of locating subsidiaries within the metropolitan area versus the global city $(b=-0.87 ; p<0.001)$.

With regards to the control variables, a high level of geographic separation between the home and host countries increases the probability of the subsidiary being located in global cities rather than in the periphery, but there is also a significant preference for the metropolitan area over the global city 
area as geographic distance increases. Additionally, cultural distance has an impact on the preference for global cities over the peripheral area, but there is also a preference for the metropolitan area over the global city area as cultural distance increases. The results also provide evidence that the service-providing industries are more drawn towards global cities than the goodsproducing industries are, and that the advanced producer services subsidiaries are clearly more prone to choose a global city location than other service-providing subsidiaries are. Finally, the number of parent-firm employees exhibits no consistent relationship with the propensity to locate in a global city.

We also conducted a number of tests for the robustness of our results to different empirical specifications and definitions of pivotal concepts included in this study. For example, we only used the bona fide alpha, beta, and gamma global cities to check if our results are unique to the way we define the global cities. We also excluded specific countries (that is, large country samples such as the USA and China, as well as home-region countries - that is, subsidiaries owned by Nordic MNEs that are located in Nordic countries) from our analyses to see whether these drive the results. Comfortingly, while levels of significance and coefficient sizes vary across different empirical specifications, our conclusions do not change.

\section{DISCUSSION}

The dominant choice among the Nordic and Japanese MNEs in our sample was to locate their foreign subsidiaries within global cities $(43 \%)$ or their corresponding metropolitan areas (32\%) where the 'more' global cities attract the largest share of the subsidiaries. This result corroborates the findings of Goerzen et al. (2013). So, even when MNEs are offshoring their operations and moving back-office operations to outlying suburbs (Cohen, 2000), global cities act as central 
places for globalization (Sassen, 2005) by attracting the majority of MNEs' subsidiaries. Since MNEs are the dominant players in the ongoing process of globalization (McCann, 2008, 2011; Beugelsdijk et al., 2010), their patterns of colocation in and around global cities influence the evolution and development of these places (Goerzen et al., 2013) and, through the centrality and global connectivity of global cities, also the overall process of globalization.

Our findings stress not only the great importance of considering subnational levels when analysing investment location decisions or the ongoing process of globalization (Brown et al., 2010; Goerzen et al., 2013), but also that LoF caused by institutional distance is different on subnational levels. The result that global cities are the preferred location for MNEs' subsidiaries when institutional distance is large highlights that microlocational advantages might lead to differences in the institutional environments on the subnational level that influence the strength of LoF.

By providing empirical support to the argument that the interrelated trinity of locational advantages of global cities helps to reduce liability of foreignness, we have therefore enhanced our limited understanding of the geographic aspect of MNE behaviour (McCann, 2011).

A practical implication of this finding is that MNE managers can view institutional distance as a source of competitive (dis)advantage (Xu, Pan, \& Beamish, 2004) that can be mitigated and/or exploited through subnational location strategies. In addition to reducing LoF, by locating in a global city firms could take advantage of creative diversity (Zaheer, Schonmaker, \& Nachum, 2012) or fill out institutional voids (Khanna, Palepu, \& Sinha, 2005) from a privileged location. In contrast, peripheral locations could allow for arbitration of the differences between the home and host country of the MNEs, which could be relevant for many MNEs in labour-intensive industries (Ghemawat, 2007). As Khanna and Palepu (2010) argue, the lack of certain institutions in emerging markets is the primary exploitable characteristic for MNEs. 
Therefore, as a result of the wide range of large cities in developing countries that emerge as potential urban growth markets for the global economy (McKinsey Global Institute, 2011; Brookings Institution, 2012), understanding the locational attributes that attract foreign MNEs is important for policymakers and city planners alike. The growth of cities is intertwined with the dynamics of economic activity and locally agglomerated processes of relationships and production (Scott, 2001). Hence, the interesting question is not what sparked the process of urban growth but rather how it develops through the "emergence of an organized production system that is increasingly locked into the initial location by its own expanding stock of agglomeration economies in a temporal dynamic circular and cumulative causation" (Storper \& Scott, 2009, p.158). In other words, cities and firms coevolve over time through interfirm networks, local labour markets, and innovation processes. Since MNEs are increasingly the loci for jobs, products, knowledge, and technologies, their attraction to certain places influences the development of these localities by promoting a cosmopolitan environment and global interconnectedness and by attracting advanced producer services.

In addition, the high number of subsidiaries located in the metropolitan area of global cities indicates the potential for suburban communities to target MNEs that are repelled by the centrifugal forces of global cities, such as land, commuting costs, and potential pollution and congestion. Moreover, the preference of the metropolitan area over the city itself as geographic distance increases could indicate that locating in the metropolitan area does not cancel out the benefits of international connectivity stemming from the global city. These findings are especially relevant for metropolitan areas that attempt to attract MNEs from similar institutional environments.

Our finding that the location of subsidiaries is influenced by the subsidiaries' respective industries points to the fact that global cities are not an attractive location to all kinds of MNE activity. MNEs' service-providing subsidiaries are drawn towards global cities because of the 
privileged access that they provide to cosmopolitan markets and so forth. By contrast, the diseconomies of congestion and factor price inflation, which are felt more heavily by the goodsproducing industries, make them shy away from urban agglomerations. In addition, the clear preference of the advanced producer services to locate within global cities provides empirical support to Sassen's $(1991,2005)$ argument that these highly specialized service firms agglomerate in locations where the requirements of their services are met by the unrivalled pool of talent, expertise, and clients found in global cities.

Finally, our result that the number of employees provides no significant relationship with the location of subsidiaries is similar to the findings of Goerzen et al. (2013), and so it is unclear whether large MNEs' access to significant internal pools of managerial expertise, network connections, and the like reduces their dependency on global cities or whether they actively seek out global cities for visibility and centrality.

\section{LIMITATIONS AND FUTURE RESEARCH}

Despite our overall finding that global cities offer attractive locations for the subsidiaries of MNEs from institutionally distant countries, we suggest that future research might continue our exploration of the relationship between subnational locations and their institutional environment by integrating the multitude of different MNE activities and strategic reasons for FDI. For instance, institutional distance between countries makes the transfer of strategic routines and organizational practices difficult (Kostova, 1999) and limits the transfer of cutting-edge technology (Bhaumnik \& Gelb, 2005). Therefore, MNEs might opt to locate goods-producing subsidiaries in institutionally similar countries to enable the safe transfer of both organizational practices and technology, but they might do so outside global cities to avoid outward knowledge spillovers and increased factor 
costs. By contrast, for institutionally distant countries, MNEs might choose to locate marketing- or advertising-intensive subsidiaries such as sales or distribution offices within global cities to gain access to the locational advantages and at the same time avoid the transfer of production practices and technology altogether. Thus, the locational choices of MNEs are influenced by numerous additional factors and are often further embedded in additional layers of relationships. Future research might consider firm heterogeneity and the complexity of subsidiary networks as well as their interactions at different levels.

Furthermore, future research might test if the results of our study, using an absolute measure of institutional distance, hold for MNEs from home countries that are institutionally very different from the ones in our sample. Even though Xu, Pan, and Beamish (2004) argue that MNEs from "strong" institutional environments may still lack legitimacy when situated in a "weak" institutional environment, it could be the case that strong institutional countries possess environments that are more conducive to location outside global cities. In other words, institutional distance could be more difficult in one direction (Shenkar, 2001; Zaheer, Schomaker, $\&$ Nachum, 2012).

Therefore, to enhance our understanding of the geographical aspect on MNE behaviour, we suggest including both MNEs from different institutional environments as well as considering firm heterogeneity on different levels.

\section{CONCLUSION}

In this paper we provide evidence for the importance of global cities, not only due to their centrality in the global economy, but also because of their functional capabilities that encourage or discourage the colocation of people and companies. We argue that the three interrelated 
characteristics of global cites - cosmopolitanism, availability of advanced producer services, and local and global interconnectedness - can reduce the LoF that MNEs face when conducting business abroad. We also provide evidence that the larger the institutional distance between MNEs' home and host countries, the more likely it is that MNEs' subsidiaries will be located in global cities than in other locations. In conclusion, our study enhances the understanding of the economic geography of MNEs by highlighting the importance of microlocational advantages that lead to differences in LoF that ultimately impact the locational choices made by MNEs.

\section{REFERENCES}

Alcacer, J. \& Chung, W. (2007). Location strategies and knowledge spillovers. Management Science, 53(5), pp. 760-776.

Beaverstock, J. V., Smith, R.G., \& Taylor, P.J. (1999). A roster of world cities. Cities, 16(6), pp. 445-458.

Beugelsdijk, S., McCann, P., \& Mudambi, R. (2010). Place, space and organization - economic geography and the multinational enterprise. Journal of Economic Geography, 10, pp. 485-493.

Bhaumik, S. K., \& Gelb, S. (2005). Determinants of entry mode choice of MNCs in emerging markets: Evidence from South Africa and Egypt. Emerging Markets Finance and Trade ${ }_{s}$ 41(2), pp. $5-24$.

Brookings Institution (2012). Global MetroMonitor: Slowdown, recovery, and interdependence. Washington D.C.: Metropolitan Policy Program at Brookings.

Brown, E., Derudder, B., Parnreiter, C., Pelupessy, W., Taylor, P. J., \& Witlox, F. (2010). World city networks and global commodity chains: Towards a world-systems' integration. Global Networks, 10(1), pp. 12-34.

Cohen, N. (2000). Business location decision-making and the cities: Bringing companies back. The Brookings Institution Center on Urban and Metropolitan Policy.

The Economist (2013). Special report: The Nordic countries. February 2nd, 2013.

Economist Intelligence Unit (2012). Hot spots - benchmarking global city competiveness. London, New York, Hong Kong \& Geneva: The Economist. 
Eden, L., \& Miller, S. R. (2004). Distance matters: Liability of foreignness, institutional distance and ownership strategy. Advances in International Management, 16, pp. 187-221.

Enright, M. J. (2009). The location of activities of manufacturing multinationals in the AsiaPacific. Journal of International Business Studies, 40, pp. 818-839.

Florida, R. (2004). America's looming creativity crisis. Harvard Business Review, October 2004, pp. 122-136.

Friedman, J. (1986). The world city hypothesis. Development and Change, 17, pp. 69-83.

Glaeser, E. L., \& Resseger, M. G. (2010). The complementarity between cities and skills. Journal of Regional Science, 50(1), pp. 221-244.

Ghemawat, P. (2007). Managing differences: The central challenge of global strategy. Harvard Business Review, March 2007

Globalization and World Cities Research Network (2011). The world according to GaWC 2010. http://www.lboro.ac.uk/gawc/gawcworlds.html, accessed on November 1, 2013.

Goerzen, A., Asmussen, C. G., \& Nielsen, B. B. (2013). Global cities and multinational enterprise location strategy. Journal of International Business Studies, 44, pp. 427-450.

Gordon, I, \& McCann, P. (2000). Industrial clusters: Complexes, agglomeration and/or social networks? Urban Studies, 37(3), pp. 513-532.

Hales, M., \& Pena, A. M., (2012). Global cities index and emerging cities outlook. Chicago, IL: AT Kearney.

Hall, P. (1966). The world cities. London: Heinemann.

Harvey, D. (1990). The condition of postmodernity. Cambridge, MA: Blackwell Publishers.

Hofstede Centre (2013). Country comparison. http://geert-hofstede.com/countries.html accessed on November 1, 2013.

Hymer, S. (1972). The multinational corporation and the law of uneven development. In J. Bhagwait (Ed), Economics and World Order from the 1970s to the 1990s, pp. 113-140. CollierMac-Millan, New York.

Jacobs, J. (1961). The death and life of great American cities. New York, NY: Random House.

Jacobs, J. (1969). The economy of cities. New York, NY: Vintage.

Jacobs, J. (1984). Cities and the wealth of nations. New York, NY: Random House. 
Kandogan, Y. (2012). An improvement to Kogut and Singh measure of cultural distance considering the relationship among different dimensions of culture. Research in International Business and Finance, 26(2), pp. 196-203.

Khanna, T., Palepu, K., \& Sinha, J. (2005). Strategies that fit emerging markets. Harvard Business Review, June, pp. 63-76.

Khanna, T., \& Palepu, K. (2010). Winning in emerging markets. Boston, MA: Harvard Business School Press.

Kogut, B., \& Singh, H. (1988). The effect of national culture on the choice of entry mode. Journal of International Business Studies, 19(3), pp. 411-432.

Kostova, T. (1999). Transnational transfer of strategic organizational practices: A contextual perspective. Academy of Management Review, 24, pp. 308-324.

Kostova, T. \& Zaheer, S. (1999). Organizational legitimacy under conditions of complexity: The case of the multinational enterprise. Academy of Management Review, 24(1), pp. 64-81.

Krippendorff, K. (1980). Content Analysis: An Introduction to Its Methodology. Beverly Hills, CA: Sage.

Krugman, P. (1994). Urban concentration: The role of increasing returns and transport costs. Proceedings of the World Bank Annual Conference on Development Economics. The International Bank for Reconstruction and Development.

LexisNexis (2013). Corporate affiliations. http://www.corporateaffiliations.com/, retrieved November 1, 2013.

Marshall, A. (1920). Principles of economics. Macmillan and Co., Ltd: London. 8th Edition. http://www.econlib.org/library/Marshall/marPCover.html, retrieved on March 14, 2014.

Mayer, T. \& Zignano, S. (2011). Notes on CEPII's distances measures: The GeoDist database. CEPII Working Paper No. 2011-25, Centre d'Etudes Prospectives et d'Informations Internationales.

McCann, P. (2008). Globalization and economic geography: The world is curved, not flat. Cambridge Journal of Regions, Economy and Society, 1, pp. 351-370.

McCann, P. (2011). International business and economic geography: Knowledge, time and transaction costs. Journal of Economic Geography, 11, pp. 309-317.

McKinsey Global Institute (2011). Urban world: Mapping the economic power of cities. McKinsey \& Company.

Mezias, J. M. (2002a). Identifying the liability of foreignness and strategies to minimize their effects: The case of labor lawsuit judgments in the United States. Strategic Management Journal, 23, pp. 229-244. 
Mezias, J. M. (2002b). How to identify liabilities of foreignness and asses their effects on multinational corporations. Journal of International Management, 8, pp. 265-282.

Nachum, L. (2003). Liability of foreignness in global competition? Financial service affiliates in the city of London. Strategic Management Journal, 24, pp. 1187-1208.

Nachum, L., \& Wymbs, C. (2005). Product differentiation, external economies and MNE location choices: M\&As in global cities. Journal of International Business Studies, 36(4), pp. 415-434.

Nachum, L., \& Zaheer, S. (2005). The persistence of distance? The impact of technology on MNE motivations for foreign investment. Strategic Management Journal, 26, pp. 747-767.

Pain, K. (2012). Spatial transformation of cities: Global city-region? Mega-city region? In B. Derudder, M. Hoyler, P.J. Taylor \& F. Witlox (Eds), International Handbook of Globalization and World Cities: 83-93. Cheltenham; Northampton, MA: Edward Elgar.

Porter, M. E. (1998). Clusters and the new economics of competition. Harvard Business Review, 76(6), pp. 77-90.

Porter, M. E. (2001). Regions and the new economics of competition. In A. Scott (Ed), Global city-regions: trends, theory, policy: pp. 139-152. Oxford: Oxford University Press.

Ricart, J. E., Enright, M. J., Ghemawat, P., Hart, S. L., \& Khanna, T. (2004). New frontiers in international strategy. Journal of International Business Studies, 35(3), pp. 175-200.

Riefler, P., Diamantopoulos, A., \& Siguaw, J.A. (2012). Cosmopolitan consumers as a target group for segmentation. Journal of International Business Studies, 43, pp. 285-305.

Robinson, J. (2005). Urban geography: world cities, or a world of cities. Progress in Human Geography, 29, pp. 757-765.

Sassen, S. (1991). The global city. Princeton, NJ: Princeton University Press.

Sassen, S. (2000). The global city: Strategic site/new frontier. American Studies, 41 (2/3), pp. 79-95.

Sassen, S. (2005). The global city: Introducing a concept. Brown Journal of World Affairs, 11(2), pp. $27-43$.

Scott, A.J. (2001). Globalization and the rise of city-regions. European Planning Studies, 9(7), pp. $813-826$.

Shenkar, O. (2001). Cultural distance revisited: Towards a more rigorous conceptualization and measurement of cultural differences. Journal of International Business Studies, 32(3), pp. 519535. 
Storper, M., \& Venables, A. J. (2004). Buzz: Face-to-face contact and the urban economy. Journal of Economic Geography, 4, pp. 351-370.

Storper, M., \& Scott, A. J. (2009). Rethinking human capital, creativity and urban growth. Journal of Economic Geography, 9, pp. 147-167.

Taylor, P.J. (2001). Specification of the world city network. Geographical Analysis, 33(2), pp. $181-194$.

Taylor, P.J. (2006). Cities within spaces of flows: Theses for a materialist understanding of the external relations of cities. In P. Taylor, B. Derudder, P. Saey and F. Witlox (Eds), Cities in globalization: pp. 287-297, London: Routledge.

UNCTAD (2013). World Investment Report 2013. New York and Geneva: United Nations. Wei, Y.D., \& Leung, C.K. (2005). Development zones, foreign investment, and global city formation in Shanghai. Growth and Change, 36(1), pp. 16-40.

World Economic Forum (2013). The global competitiveness report 2013-2014. Geneva: World Economic Forum. Data available from www.weforum.org/gcr.

Xu, D. \& Shenkar, O. (2002). Institutional distance and the multinational enterprise. The Academy of Management Review, 27(4), pp. 608-618.

$\mathrm{Xu}$, D., Pan, Y., \& Beamish, P. W. (2004). The effect of regulative and normative distances on MNE ownership and expatriate strategies. Management International Review, 44(3), pp. 285307.

Zaheer, S. (1995). Overcoming the liability of foreignness. Academy of Management Journal, 38(2), pp. 341-363.

Zaheer, S. \& Mosakowski, E. (1997). The dynamics of the liability of foreignness: A global study of the survival in financial services. Strategic Management Journal, 18(6), pp. 439-463.

Zaheer, S., Schomaker, M. S., \& Nachum, L. (2012). Distance without direction: Restoring credibility to a much-loved construct. Journal of International Business Studies, 43, pp. 18-27. 
Table 1: Descriptive statistics and correlations

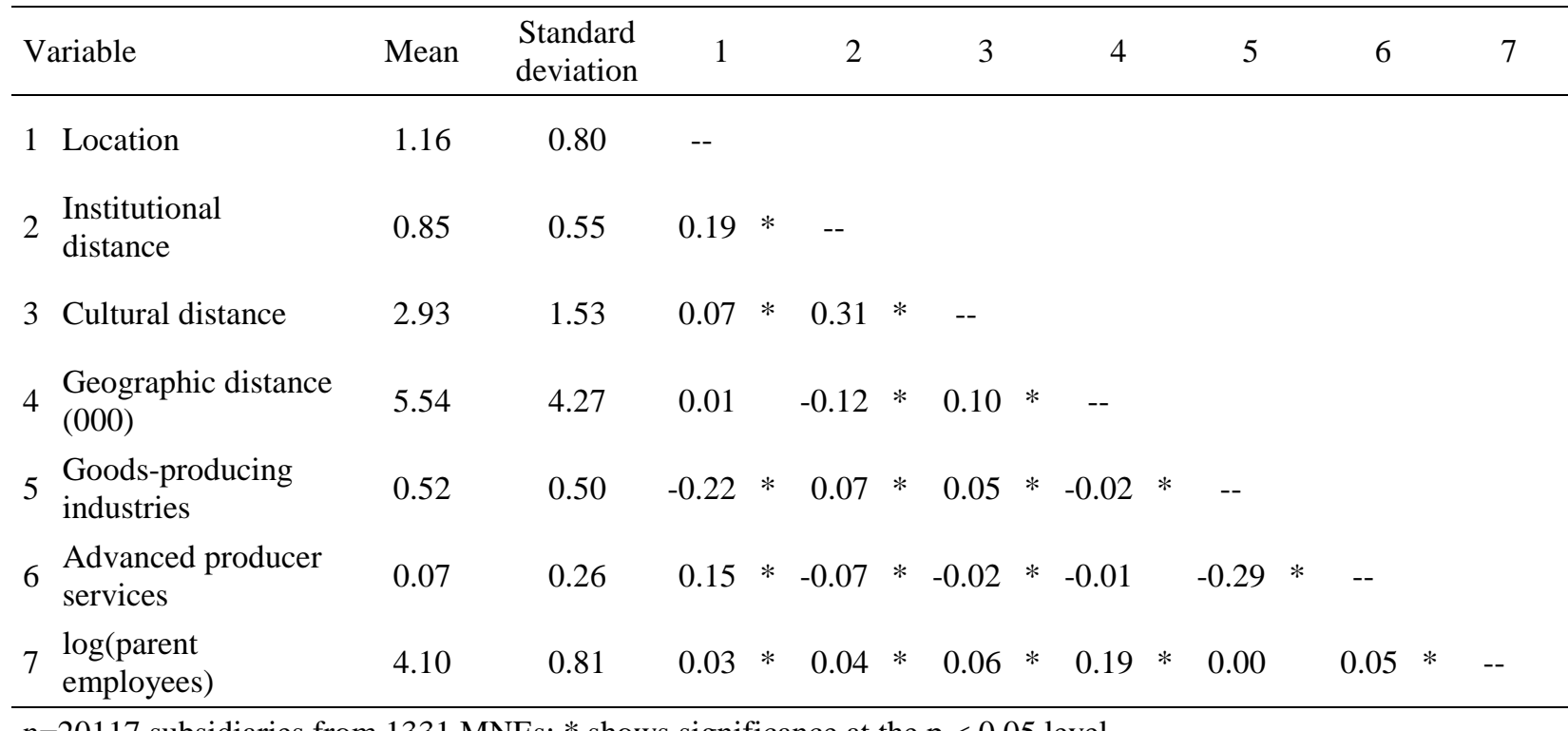

$\mathrm{n}=20117$ subsidiaries from 1331 MNEs; * shows significance at the $\mathrm{p}<0.05$ level.

Table 2: Multinomial logistic regression models of global city location

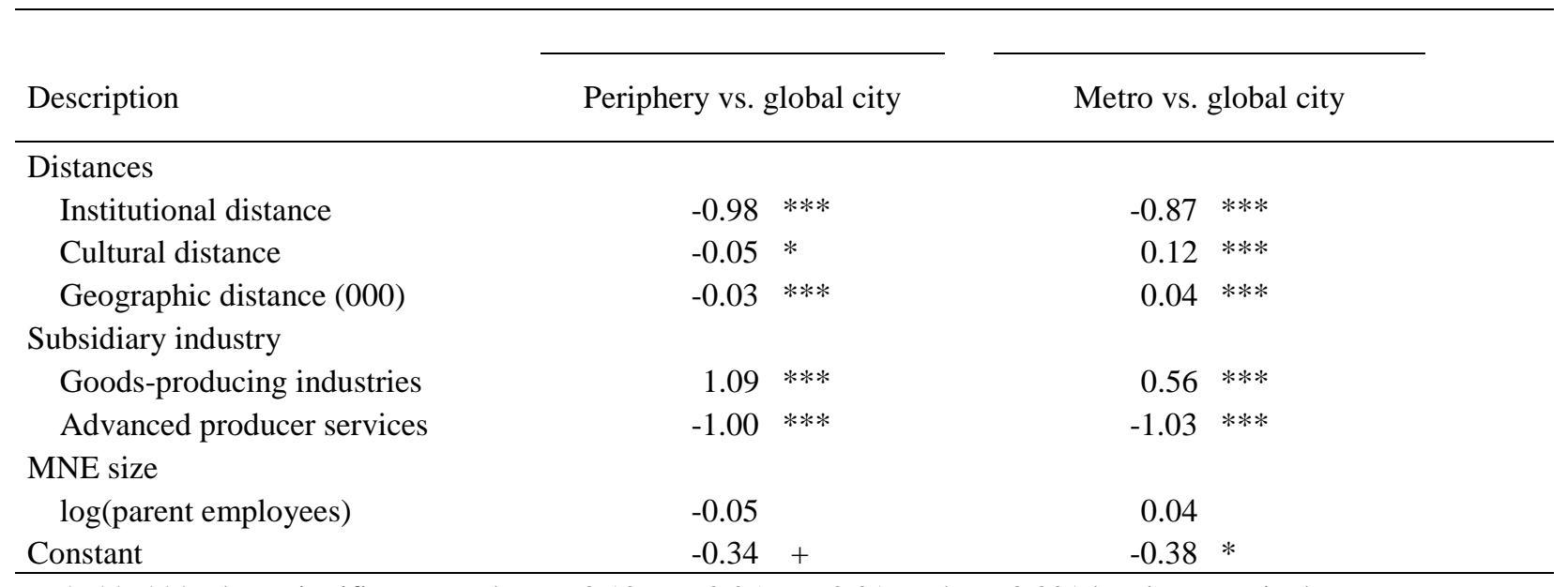

$+, * * *, * * *$, show significance at the $\mathrm{p}<0.10, \mathrm{p}<0.05, \mathrm{p}<0.01$, and $\mathrm{p}<0.001$ level, respectively 